\title{
Dam Safety: The Question of Tailings Dams
}

\author{
Nasrat Adamo', Nadhir Al-Ansari ${ }^{2}$, Varoujan Sissakian ${ }^{3}$, Jan Laue $^{4}$ \\ and Sven Knutsson ${ }^{5}$
}

\begin{abstract}
Tailings' Dams are mining waste impounding structures. They differ from conventional dams in purpose, design and operation. Percentage wise their failures are higher and posing considerably more safety concerns, causing long lasting devastation on communities, environment, and animal and plant ecosystem. Two basic types of embankment tailings structures are used for tailings impoundments; the Retention Dams and the Raised Dams. Retention dams are built in one operation to a full height, while construction of Raised Dams is a continuous process lasting for the whole useful life of the mine. Raised Dams are favored over Retention dams as they can be enlarged and expanded as the extraction works continue with time. Raised embankment dams themselves can be of three alternative designs according to the method used in construction; the Downstream, Upstream and Centerline structures. This designates the direction in which the embankment crest moves in relation to the initial embankment at the base as successive lifts are added. Resulting from the used method of tailings weight disposition, the Upstream Raised Dams are the least safe in earthquake prone areas as compared to the other two types due to its higher possibility of liquefaction, so they are not favored in highly seismic areas. The disadvantage of Downstream Raised Dams is their use of larger land areas. Centerline Raised Dams are a compromise between the other two. Tailing Dams failure may occur due to: dam instability, overtopping, internal erosion, or combination of these. Instability can result from faulty design and/ or faulty tailings deposition method. Internal erosion can follow saturation of the fill due to fast rate of work and close proximity of the water pond to the dyke combined with
\end{abstract}

\footnotetext{
${ }^{1}$ Consultant Dam Engineer, Sweden.

${ }^{2}$ Lulea University of Technology, Lulea 971 87, Sweden.

${ }^{3}$ Lecturer, University of Kurdistan Hewler and Private Consultant Geologist, Erbil.

${ }^{4}$ Lulea University of Technology, Lulea 971 87, Sweden.

${ }^{5}$ Lulea University of Technology, Lulea 971 87, Sweden.
} 
downstream gullying, and overtopping happens in case of faulty water management and/ or inoperable decan system. Careful analysis of historic failures and drawing out new lessons from them can help reducing failure probability and enhance tailings' dams' safety.

Keywords: Tailings, tailings dams, mining, retention dams, raised dams, downstream structure, upstream structure, centerline structure, dam instability, overtopping, internal erosion, decant system.

\section{General}

Tailings Dam is typically an earth-fill embankment dam used to store commercially worthless material that surrounds, or is closely mixed with, a wanted mineral in mining operations after separating the ore. Tailings themselves can be liquid, solid, or a fluid of fine particles, and are usually highly toxic and potentially radioactive. Solid tailings are often used as part of the dam structure itself. The contents of the tailings depend on what mineral is being mined. More than half of the material removed from mines is cast away immediately, then only the ore-containing the required material is processed, by grinding it up to very small particles, and then using some chemical additives to extract the wanted material.

Normally, the salvaged material is less than $1 \%$ of the original material put through the processing. So, this usually ends up with a lot of waste. The waste often is in the form of a slurry: a fairly even combination of solid waste and water. A slurry's specific contents vary based on the type of mining being done and where the mine is located [1].

Many of the mined minerals are called sulfide minerals. The most common sulfide mineral is the iron sulfide "pyrite". So, when pyrite is exposed to oxygen and to water it breaks down chemically into a weak sulfuric acid. That acid, in turn, will dissolve some of these other accompanying sulfide minerals that contain lead, zinc, cadmium, selenium, arsenic, and a whole host of other things that can be dangerous for the environment.

Mining of copper, gold, uranium and other mining operations similarly produces various kinds of waste; much of it is toxic or radioactive, which pose varied challenges for long-term containment. Traditionally, around $90 \%$ of gold is processed using hazardous chemicals like cyanide or mercury. Using these toxic chemicals to release fine gold ores from rock is a process that has existed for over 100 years. These toxic chemicals are often expelled into tailing dams with waste water from the extraction process.

Even if the dam does not collapse, these highly poisonous substances can still leach into the local surrounds, or ground water contaminating the soil and water supply. Dam's collapsing, however, means not only overflooding large areas and the possible destruction of communities causing human fatalities, but also spreading toxic materials over extensive terrain with long lasting damage inflicted on the environment. For a person, just a grain-sized dose of cyanide or 1.5 grams of 
mercury is deadly. For fish, trace amounts of cyanide would prove fatal. This means that tailing's dams' safety is a paramount matter that should be taken seriously by all concerned.

Tailings' Dams rank among the largest engineered structures on earth. The Syncrude Mildred Lake Tailings Dyke in Alberta, Canada, is an embankment dam about $18 \mathrm{~km}$ long and between 40 to $88 \mathrm{~m}$ high. It is the largest dam structure on earth by volume fill, as of 2001. It is located $40 \mathrm{~km}$ north of Fort McMurray, Alberta, at the northern end of the Mildred Lake. The dam and the tailings artificial lake within it are constructed and maintained as part of ongoing operations in extracting oil from the Athabasca oil sands. Other tailings' dams constructed and operated in the same area include the Southwest Sand Storage (SWSS), which is the third largest dam in the world by volume of construction material after the Tarbela Dam. The facility was designed to provide coarse tailings sand storage, returning water and thin fine tailings to other sites within the Mildred Lake Project area [2].

Tailings' Dams are much different from the familiar conventional dams which serve the multipurpose objectives of flood control, storage of water for agriculture and drinking water in addition to power generation. Tailings dams are meant for permanent storage of unwanted materials and have different design and methods of construction. As such Tailings Dams present different challenges to the geotechnical engineers than those they face with conventional dams.

i) Facts that need to be recognized at the start of any Tailings Dam developments are: These dams must remain structurally competent in "perpetuity" (perpetuity is a long time) and cannot be breached upon project completion.

ii) They are constantly changing in size and often reaching hundreds of millions or, occasionally exceeding one billion of tons of material to utilize or store.

iii) They are in ever changing states of stress.

iv) Typically, under construction for at least 5 to 10 years, but construction can be extended to periods of more than 50 or even 100 years.

v) They are susceptible to brittle undrained loading response.

vi) Tailings Dams have no ability to generate revenue for their owner, as opposed to hydro-electric dams for example, and so generally thought of as burdens rather than assets and an annoying way of doing costly business.

vii) They seldom have owners who are familiar with all the key geotechnical issues facing these facilities and thus putting such responsibility on the consulting designer [3]. 


\section{Tailings Dams Failures and Consequences}

It is estimated from information available in 2000, there were at least 3,500 tailings dams around the world. But, as there are around 30,000 industrial mines, the number of tailings dams is likely to be much higher [4]. This number is not confirmed due to the unavailability of complete inventory and the total number is disputed. These structures experience known "major" failures of about 2 to 5 annually, along with 35 "minor" failures. Assuming the 3,500 figure is correct, this failure rate is more than two orders of magnitude higher than the failure rate of conventional water retention dams.

In one publication from 2001 of ICOLD-UNEP, it estimated the number of major incidents with Tailings Dams were continuing at an average of more than one per year. During the 6 years previous to that, the rate had been two per year. Trying to determine the causes of these incidents, 221 case records were collected. The main causes of the reported failures and incidents cases were found to be:

1) Loss of control over water balance.

2) Lack of control over construction.

3) A general lack of understanding of the features that govern safe operations.

There were one or two cases of unpredictable events and other cases caused by unexpected climatic and natural conditions, including earthquakes [5].

List of Tailings Dams failure, prepared by the World Information Service on Energy Projects (WISE) and updated on $2^{\text {th }}$ December 2019, documents 126 failures of various sizes and types of Tailings Dams for the period 1961-2019 giving an average of about two cases per year. But due to limited availability of data, this compilation is considered in no way complete.

An abridged list drawn by the writer from (WISE) list is presented in Table 1, showing only some arbitrary selected cases to indicate countries where major failures occurred, and illustrate a type of mining operations and the type of extracted ore, in addition to size and extent of the resulting damage [6]. 
Table 1: Chronology of major tailings dam failures (1961-2019).

\begin{tabular}{|c|c|c|c|c|}
\hline Date & Location & Ore Type & Incident Type & \\
\hline 2019, July 10 & $\begin{array}{l}\text { Peru, Corbiza } \\
\text { mine }\end{array}$ & Copper & $\begin{array}{l}\text { Tailings Dam } \\
\text { Failure }\end{array}$ & $\begin{array}{l}67,488 \mathrm{~m}^{3} \text { tailing release, covering } \\
41,574 \mathrm{~m}^{2}\end{array}$ \\
\hline 2019, Jan. 25 & $\begin{array}{l}\text { Brazil, Córrego de } \\
\text { Fejăo mine }\end{array}$ & Iron & $\begin{array}{l}\text { Tailings Dam } \\
\text { Failure }\end{array}$ & $\begin{array}{l}12 \text { million } \mathrm{m}^{3} \text { of tailings wave } \\
\text { travelling } 7 \mathrm{~km} \text { destroying infra } \\
\text { structures killing } 259 \text { people }\end{array}$ \\
\hline 2018, Mar. 9 & $\begin{array}{l}\text { N. S. W. } \\
\text { Australia, Cadia }\end{array}$ & $\begin{array}{l}\text { Gold, } \\
\text { copper }\end{array}$ & $\begin{array}{l}\text { Tailing Dam } \\
\text { Failure }\end{array}$ & $\begin{array}{l}1.33 \text { million tons of tailings. Failure due } \\
\text { to low density foundation layer in the } \\
\text { vicinity of slump }\end{array}$ \\
\hline 2016, Aug.27 & $\begin{array}{l}\text { USA, Florida, } \\
\text { New Wales Plant }\end{array}$ & Phosphate & $\begin{array}{l}\text { Sinkhole in the } \\
\text { phosphate- } \\
\text { gypsum stack }\end{array}$ & $\begin{array}{l}840,000 \mathrm{~m}^{3} \text { of liquid released as of Sep. } \\
2016 \text { contaminating a major the Floridan } \\
\text { aquifer ; a major source of drinking } \\
\text { water }\end{array}$ \\
\hline 2015, Nov.5 & $\begin{array}{l}\text { Brazil, Germano } \\
\text { mine }\end{array}$ & Iron & $\begin{array}{l}\text { Tailings Dam } \\
\text { Failure due to } \\
\text { insufficient } \\
\text { drainage leading } \\
\text { to liquefaction } \\
\text { after a small } \\
\text { earthquake }\end{array}$ & $\begin{array}{l}32 \text { million } \mathrm{m}^{3} \text { slurry wave causing } 158 \\
\text { homes destroyed, } 17 \text { persons killed in } \\
\text { nearby town of Bento Rodrigues. } \\
\text { Polluting North Gualaxo River, Carmel } \\
\text { River and Doce }\end{array}$ \\
\hline 2014, Aug.4 & $\begin{array}{l}\text { British Colombia, } \\
\text { Mount Polley } \\
\text { mine }\end{array}$ & $\begin{array}{l}\text { Copper, } \\
\text { Gold }\end{array}$ & $\begin{array}{l}\text { Tailings Dam } \\
\text { Failure due to } \\
\text { foundation } \\
\text { failure }\end{array}$ & $\begin{array}{l}7.3 \text { million } \mathrm{m}^{3} \text { of tailings, } 10.6 \text { million } \\
\mathrm{m}^{3} \text { of water and } 6.5 \mathrm{~m}^{3} \text { of interstitial } \\
\text { water flowing into Polley Lake and, } \\
\text { through Hazeltine Creek into Quesnel } \\
\text { Lake }\end{array}$ \\
\hline 2012, Aug.1 & $\begin{array}{l}\text { Philippines, } \\
\text { Padcal mine } \\
\end{array}$ & $\begin{array}{l}\text { Copper, } \\
\text { gold }\end{array}$ & $\begin{array}{l}\text { Tailings Pond } \\
\text { breach }\end{array}$ & $\begin{array}{l}20.6 \text { million tons of tailings } \\
\text { discharged into Balog River }\end{array}$ \\
\hline 2009, Aug.29 & $\begin{array}{l}\text { Russia, } \\
\text { Karamaken } \\
\text { Mineral } \\
\text { Processing plant } \\
\end{array}$ & Gold & $\begin{array}{l}\text { Tailings Dam } \\
\text { Failure after } \\
\text { heavy rain }\end{array}$ & $\begin{array}{l}\text { More than } 1 \text { million } \mathrm{m}^{3} \text { of water, } 150.000 \\
\mathrm{~m}^{3} \text { of tailings and } 55.000 \mathrm{~m}^{3} \text { of dam } \\
\text { material. eleven homes washed away by } \\
\text { mud flow, one person killed }\end{array}$ \\
\hline 2007, Jan 10 & Brazil, Mirai & Bauxite & $\begin{array}{l}\text { Tailings Dam } \\
\text { Failure }\end{array}$ & $\begin{array}{l}2 \text { million } \mathrm{m}^{3} \text { of mud of clay and water } \\
\text { left } 4000 \text { residents homeless, crops and } \\
\text { pastures destroyed, water supply } \\
\text { compromised }\end{array}$ \\
\hline 2005, April14 & $\begin{array}{l}\text { USA, Mississippi, } \\
\text { Jackson county }\end{array}$ & Phosphates & $\begin{array}{l}\text { Phospho- } \\
\text { gypsum stack } \\
\text { failure }\end{array}$ & $\begin{array}{l}17 \text { million gallon of acidic liquid }(64,350 \\
\left.\mathrm{m}^{3}\right) \text {. Liquid poured into adjacent marsh } \\
\text { lands }\end{array}$ \\
\hline 2004 , Sep. 5 & $\begin{array}{l}\text { USA, Florida, } \\
\text { Riverview }\end{array}$ & Phosphates & $\begin{array}{l}\text { Dike on } 100 \\
\text { gypsum stack } \\
\text { holding } 150 \\
\text { million gallons } \\
\text { of polluted } \\
\text { water broke } \\
\text { after waves } \\
\text { driven by } \\
\text { Hurricane } \\
\text { Frances bashed } \\
\text { the dike }\end{array}$ & $\begin{array}{l}60 \text { million gallons }\left(227,000 \mathrm{~m}^{3}\right) \text { acidic } \\
\text { liquid spilled into Archie Creek leading } \\
\text { to Hillsborough Bay }\end{array}$ \\
\hline
\end{tabular}




\begin{tabular}{|c|c|c|c|c|}
\hline 2000, Oct.11 & $\begin{array}{l}\text { USA, Kentucky, } \\
\text { Inzes }\end{array}$ & Coal & $\begin{array}{l}\text { Tailings Dam } \\
\text { Failure }\end{array}$ & $\begin{array}{l}250 \text { million gallons }\left(950.000 \mathrm{~m}^{3}\right) \text { of } \\
\text { coal waste. } 120 \mathrm{~km} \text { of rivers turned } \\
\text { iridescent black casing fish kill }\end{array}$ \\
\hline 2000, Sep. 8 & $\begin{array}{l}\text { Sweden, Aitiki } \\
\text { mine }\end{array}$ & Coper & $\begin{array}{l}\text { Tailings Dam } \\
\text { Failure }\end{array}$ & $\begin{array}{l}2.5 \text { million } \mathrm{m}^{3} \text { of liquid released into } \\
\text { settling pond and releasing } 1.5 \text { million } \\
\mathrm{m}^{3} \text { of slurry into adjacent environment }\end{array}$ \\
\hline 1995, Aug.19 & Guyana, Omai & Gold & $\begin{array}{l}\text { Tailings Dam } \\
\text { Failure }\end{array}$ & $\begin{array}{l}4.2 \text { million } \mathrm{m}^{3} \text { of cyanide slurry causing } \\
\text { environmental disaster }\end{array}$ \\
\hline 1994, Nov.19 & $\begin{array}{l}\text { USA, Florida } \\
\text { Hopewell mine }\end{array}$ & Phosphate & $\begin{array}{l}\text { Tailings Dam } \\
\text { Failure }\end{array}$ & $\begin{array}{l}1.9 \text { million } \mathrm{m}^{3} \text { of water from clay settling } \\
\text { pond spill into nearby wetland and Alafia } \\
\text { River, Keysville flooded }\end{array}$ \\
\hline 1994, Oct. 2 & $\begin{array}{l}\text { USA, Florida, } \\
\text { Pine Creek mine }\end{array}$ & Phosphate & $\begin{array}{l}\text { Tailings Dam } \\
\text { Failure }\end{array}$ & $\begin{array}{l}6.8 \text { million of water from clay settling } \\
\text { pond. } 500.000 \mathrm{~m}^{3} \text { released into Hickey } \\
\text { Branch a tributary of Payne Creek }\end{array}$ \\
\hline 1994, Feb. 14 & $\begin{array}{l}\text { South Australia, } \\
\text { Olympic Dam, } \\
\text { Roxby Downs } \\
\end{array}$ & $\begin{array}{l}\text { Copper, } \\
\text { Uranium }\end{array}$ & $\begin{array}{l}\text { Tailings Dam } \\
\text { Leakage }\end{array}$ & $\begin{array}{l}5 \text { million } \mathrm{m}^{3} \text { release of contaminated } \\
\text { water into subsoil }\end{array}$ \\
\hline 1992, Jan. & $\begin{array}{l}\text { Philippines, } \\
\text { Padcal mine }\end{array}$ & Copper & $\begin{array}{l}\text { Collapse of dam } \\
\text { wall }\end{array}$ & 80 million tons...? \\
\hline 1982, Nov. 8 & $\begin{array}{l}\text { Philippines, } \\
\text { Spialay }\end{array}$ & Copper & $\begin{array}{l}\text { Tailings Dam } \\
\text { Failure }\end{array}$ & $\begin{array}{l}28 \text { million tons inundation of agricultural } \\
\text { land up to } 1.5 \mathrm{~m} \text { depth }\end{array}$ \\
\hline 1980, Oct. 13 & $\begin{array}{l}\text { USA, New } \\
\text { Mexico, Tyrone }\end{array}$ & Copper & $\begin{array}{l}\text { Tailings Dam } \\
\text { Breach }\end{array}$ & $\begin{array}{l}2 \text { million } \mathrm{m}^{3} \text { tailings flow } 8 \mathrm{~km} \\
\text { inundating farmland }\end{array}$ \\
\hline 1974, Nov.11 & $\begin{array}{l}\text { South Africa, } \\
\text { Bafokeng }\end{array}$ & Platinum & $\begin{array}{l}\text { Embankment } \\
\text { Failure }\end{array}$ & $\begin{array}{l}3 \text { million } \mathrm{m}^{3}, 12 \text { people killed, tailings } \\
\text { flow travelled } 45 \mathrm{~km}\end{array}$ \\
\hline 1965, Mar. 28 & $\begin{array}{l}\text { Chile, El Cobre, } \\
\text { New and Od } \\
\text { Dams }\end{array}$ & Copper & $\begin{array}{l}\text { Liquefaction } \\
\text { dam failure } \\
\text { during } \\
\text { earthquake } \\
\end{array}$ & $\begin{array}{l}350,000 \mathrm{~m}^{3} \text { and } 1.9 \text { million } \mathrm{m}^{3} \text {, tailings } \\
\text { travelled } 12 \mathrm{~km} \text { killing more than } 200 \\
\text { people }\end{array}$ \\
\hline 1962, Sep. 26 & $\begin{array}{l}\text { China, Huogudi, } \\
\text { Gejiu, Yunnan }\end{array}$ & Tin & $\begin{array}{l}\text { Failure of } \\
\text { upstream dam } \\
\text { due to moderate } \\
\text { rain }\end{array}$ & $\begin{array}{l}\text { Tailings travelled } 4.5 \mathrm{~km} \text {, destroying } 11 \\
\text { villages, } 171 \text { people killed, } 92 \text { injured } \\
13,970 \text { homeless }\end{array}$ \\
\hline
\end{tabular}

Failure of tailings storage facilities (TSF) can have disastrous consequences for nearby communities, the environment, and for the mining companies, who may consequently, face high financial and reputational costs. In 2015, the breach of the Fundão Tailings Dam at Samarco mine in Minas Gerais resulted in 19 fatalities, and was declared the worst environmental disaster in Brazil's history. In settlement of the claims resulting from this failure, the owners had to agree on a settlement plan costing $\$ 2.4$ billion to remediate and compensate for the impacts over a 15 years; moreover, twenty-one company executives were charged with qualified murder. The ecosystems impacts caused by any failure can last for many years depending on the nature of the tailings. In the above mentioned example, the owning company is in the process of restoring 5000 streams, 16,000 hectares of "Permanent Conservation Areas" along the Doce River basin, and 1200 hectares in the riverbanks. It is estimated that the livelihoods of more than 1 million people were affected because of the failure. 
Improvements in the design, monitoring, management, and risk analysis of Tailings Dams facilities are needed to prevent future failures and mitigate the consequences of a breach [7].

\section{Tailings Dams Types and Their Construction Methods- Their Pros and Cons}

Two basic types of embankment structures are used for retaining tailings in impoundments; these are the Retention Dams and the Raised Dam. Retention dams are similar to conventional dams in regard to soil properties, surface water and ground water controls, and stability; they are built in one operation till completion to a full height at the beginning of the disposal operations. On the other hand, construction of Rising Tailings Dams is a continuous process which lasts for the whole useful life of the mining project depending on the size of the mine and its capacity. In both cases, suitable site is chosen first to contain the mining operations' wastes.

Typically for a rising tailing dam, a base or starter embankment is constructed first; this is done by surrounding the pre-selected terrain for the site by primary embankment, which may take the shape of a circular ring or any other shape depending on the topography of the terrain to form an enclosure. The embankment may be built of material consisting of natural soils, mine overburden, other current mine waste or tailings from a preexisting tailings deposits. Alternatively, and more commonly, the outer embankment is built of current tailings production. If the tailings comprise a wide range of particle sizes, it is a common practice to separate the sand (coarse fraction) from the slimes (fine fraction); first. The sand is used to build the outer embankment or shell of the impoundment, while the slimes are delivered into the body of the impoundment. When the tailings have a narrow range of particle sizes and the fine fraction is not clayey, the total product may be used to build the outer embankment. Since the object of a tailings dam is to retain solids, not water, the embankments are usually designed to be as pervious as possible [8]. An aerial view of Wheal Jane tin mine in Figure 1, is an example of tailings dam layout utilizing shape of the surrounding terrain [9]. This tailings dam was opened in mid-18 ${ }^{\text {th }}$ century and closed in 1992 in West Cornwall, England [10]. 


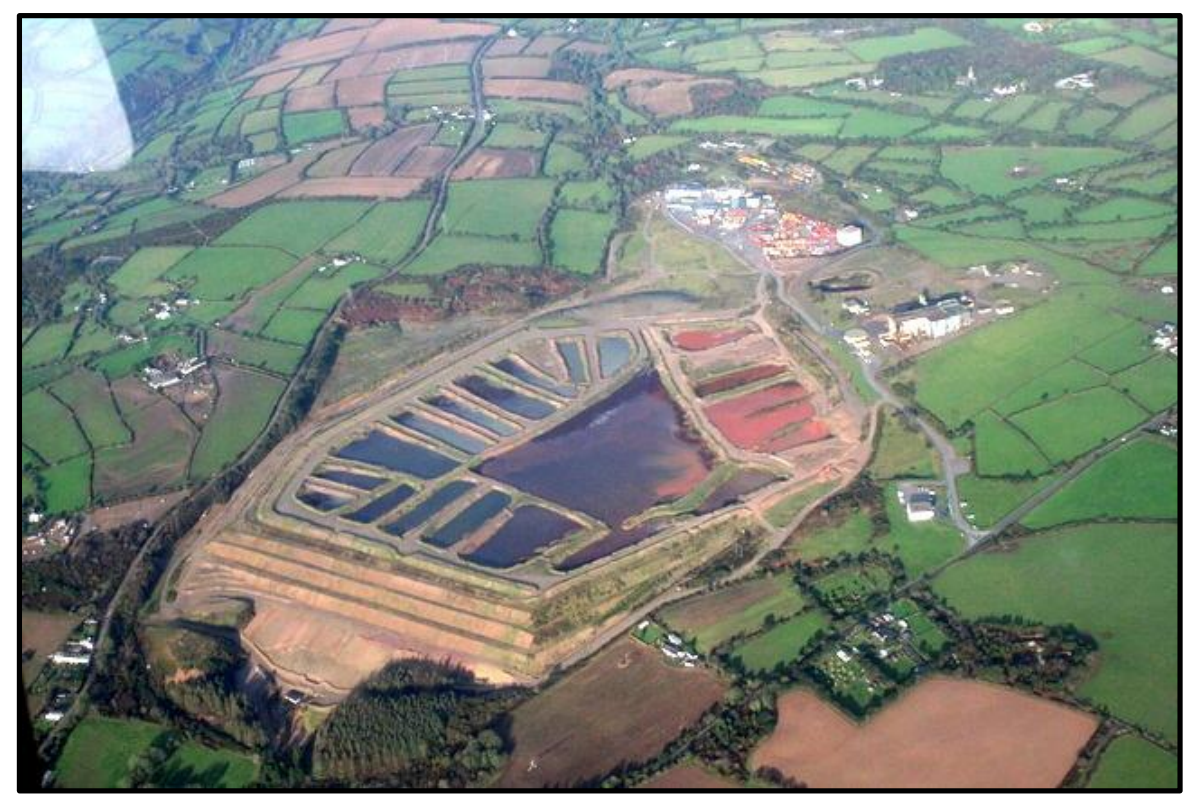

Figure 1: Aerial view of Wheal Jane tin mine Tailings Dam [9].

The enclosed area of impoundment may be one of four types; the Ring-Dike, In-Pit, Specially Dug Pit, and variations of the Valley design. The design choice is primarily dependent upon natural topography, site conditions, and economic factors. Most tailings dams in operation today are a form of the Valley design due to lesser volume of fill material and maximizing the use of local materials, particularly the tailings themselves which results in lesser overall cost. Tailings Retention Dams are suitable for any type of tailings and deposition method but commonly less used than the Raised Tailings Dams; typical cross section of such a type is shown in Figure 2 [11].

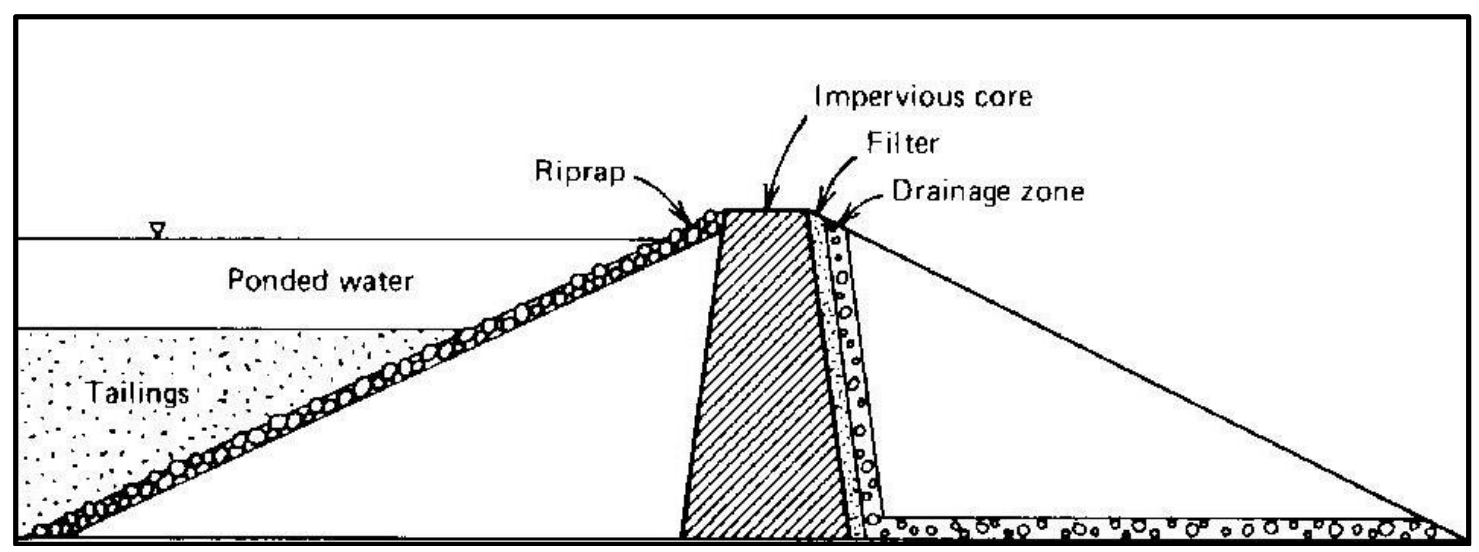

Figure 2: Typical cross section of Retention Type Dam for Tailings Disposal [11]. 
Raised Tailings Dams can be of three alternative designs according to the method used in construction; the Downstream, Upstream and Centerline Structures, which designate the direction in which the embankment crest moves in relation to the initial embankment at the base as the embankment is raised in successive lifts to increase the available volume for the storage of tailings and water.

The Upstream Method is the lowest initial cost alternative due to the minimal amount of fill material required for initial construction, and it is a more popular type of raised tailings dams in low risk seismic areas. The construction starts with a pervious starter dyke foundation, then tailings are discharged from the top of the dam crest creating a beach that becomes the foundation for future embankment raises. Figure 3 shows a diagram of the stages of construction of an upstream raised embankment.

By natural segregation, coarse material settles first and the fines furthest away. Cyclones can be used to accelerate this particle segregation for certain tailings by sending the slime proportion to the center of the impoundment and the sand fraction to the beach behind the crest.

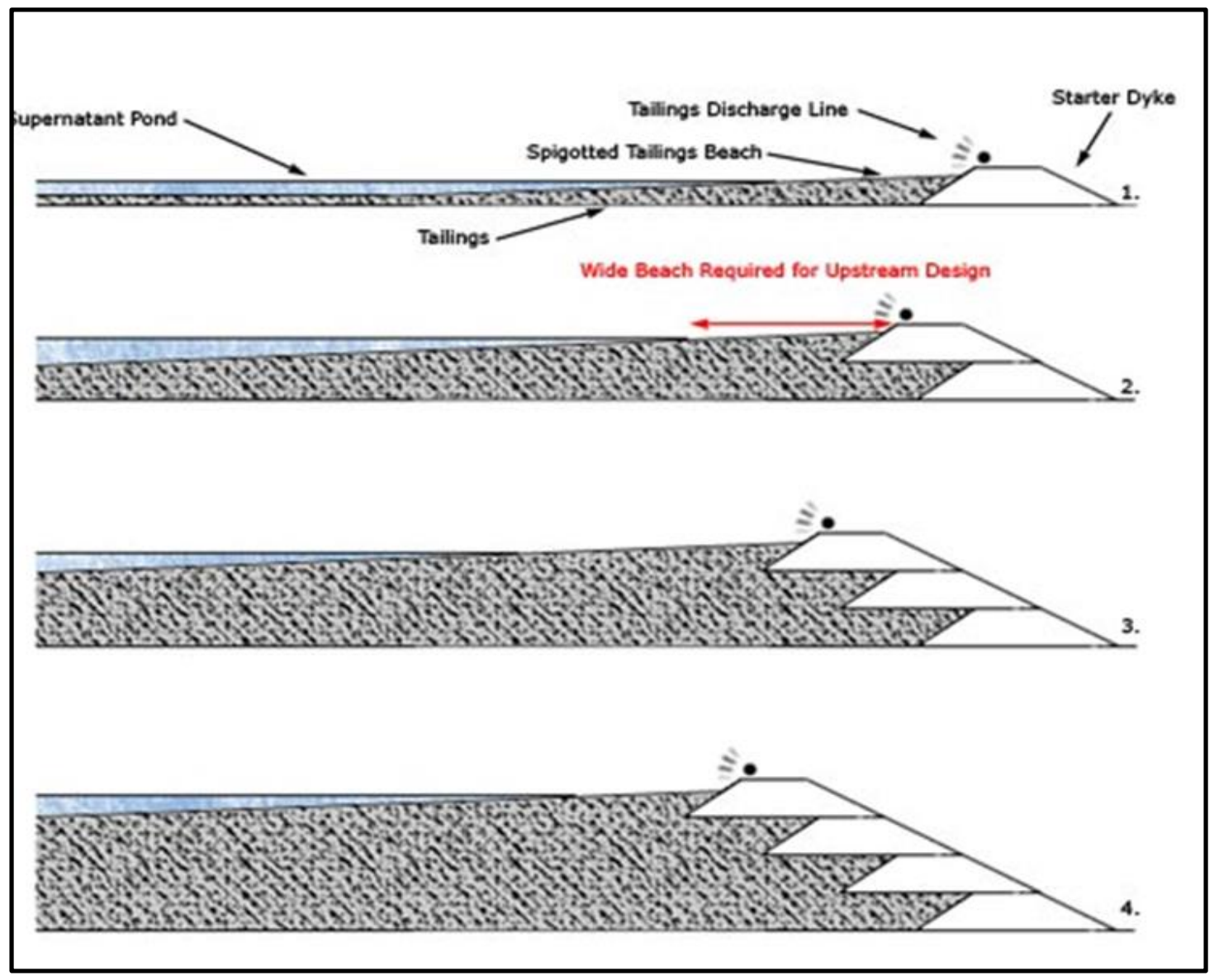

Figure 3: Upstream method of embankment construction. 
The conventional method of upstream raises relies on consolidation of the beach that forms the embankment shell under its self-weight, but today, compaction has become more common using earthmoving equipment to increase the degree of safety of raised embankments. Once the tailings have dried and consolidated, and tailings placed on the embankment crest and compressed, then tailings discharge lines are lifted and reassembled, and the next riser is started.

It is noted that the Upstream Tailings Dams failures are the more reported cases of failures causing huge environmental consequences all over the world. Records show that out of the just over 3500 tailings dams worldwide; 50\% are of this design, and it was observed that the key failure mode of upstream embankments is a static/ transient load which induced liquefaction flow slide event. This is not surprising considering the low relative density of the tailings and the potential for water mismanagement to generate high saturation of the embankment and subsequently creating liquefaction induced flows of the tailings.

The high rate of failures of Upstream Tailings Dams has led to the development of the Downstream Embankment design to reduce the safety risks associated with the upstream design, particularly when subjected to be dynamic loading as a result of earthquake shaking. The installation of impervious cores and drainage zones can also allow the impoundment to hold a substantial volume of water directly against the upstream face of the embankment without jeopardizing stability. Construction of such a dam begins with an impervious starter dyke which is provided with internal drainage arrangement, unlike the upstream design that has a pervious starter dyke. The tailings are at first deposited behind the dyke and as the embankment is raised; the new section is constructed and supported on top of the downstream slope of the previous section. This shifts the centerline of the top of the dam downstream as the embankment stages are progressively raised, Figure 4.

An advantage to the downstream design is that the raised sections can be designed to be of variable porosity to tackle any problems with the phreatic surface of the embankment. This can be particularly useful where a processing plant has made changes to increase efficiency and as a result alter the tailings characteristics. This may result in pumping more water to the tailings facility or alter the drainage characteristics of the newly deposited tailings. 


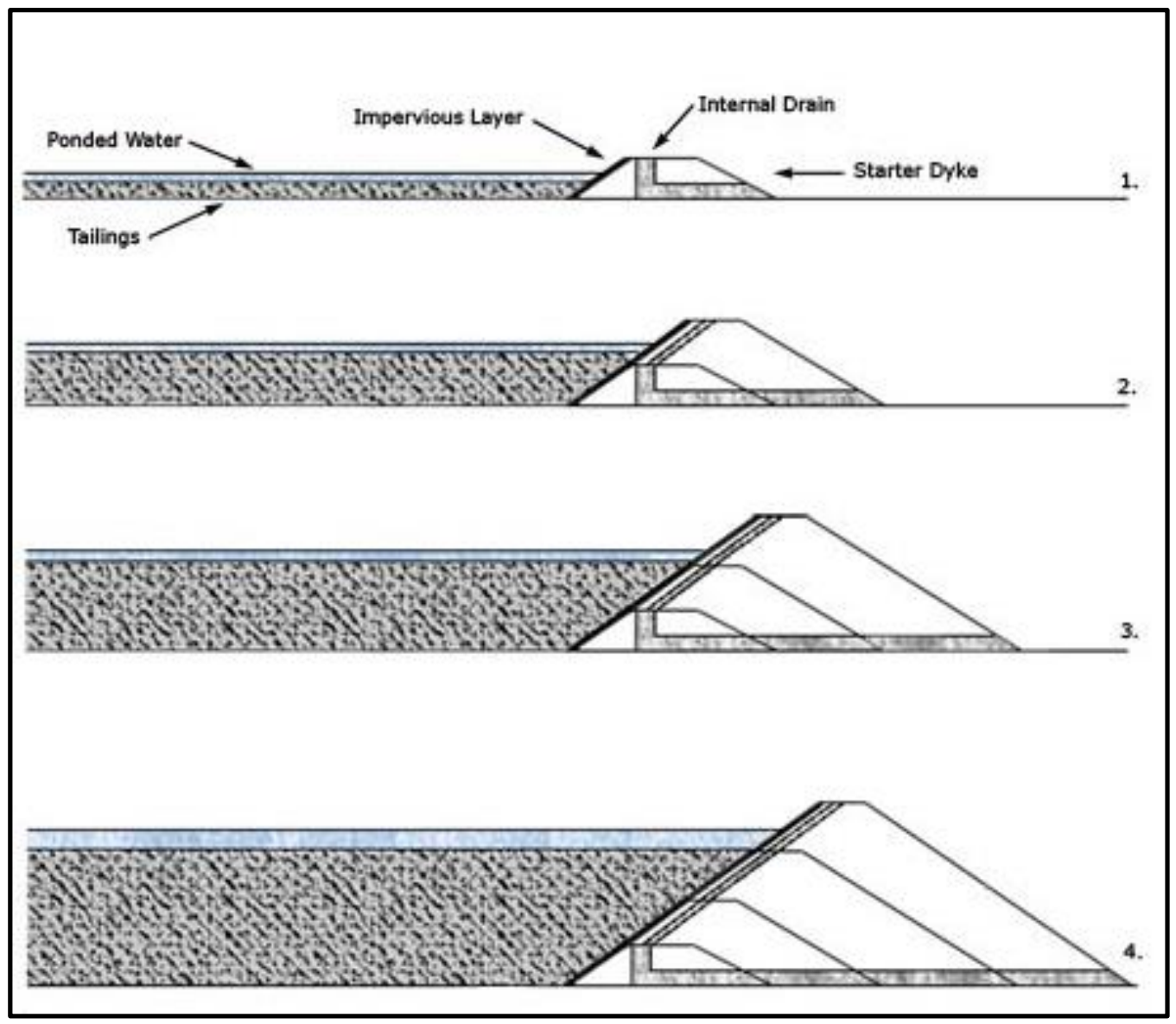

Figure 4: Downstream method of embankment construction.

The downstream design is very versatile for a range of site specific design parameters and behaves similarly to water retention dams. Its main advantage is it can have unrestricted heights due to each raise being structurally independent of the tailings. The main disadvantage is the requirement of a large area around the dam itself as the toe of the dam moves out when more raises are added. This can cause problems where limited space is available, and can add up more cost for the acquisition of the required land area. Although a downstream embankment can theoretically have no height limit, the dam's ultimate height is determined by the restriction of the advancing toe. The raised dams are definitely more safe than impounded dams.

An improvement over two previous designs is the Centreline Type Tailings Dams. It is more stable than the upstream method, but does not require as much construction material as the downstream design. Like the upstream method, the tailings are generally discharged by spigots from the embankment crest to form a beach behind the dam wall. When subsequent raising is required, material is placed on both the tailings and the existing embankment. The embankment crest is being 
raised vertically and does not move in relation to the upstream and downstream directions of subsequent raises, hence the term, centreline design (Figure 5).

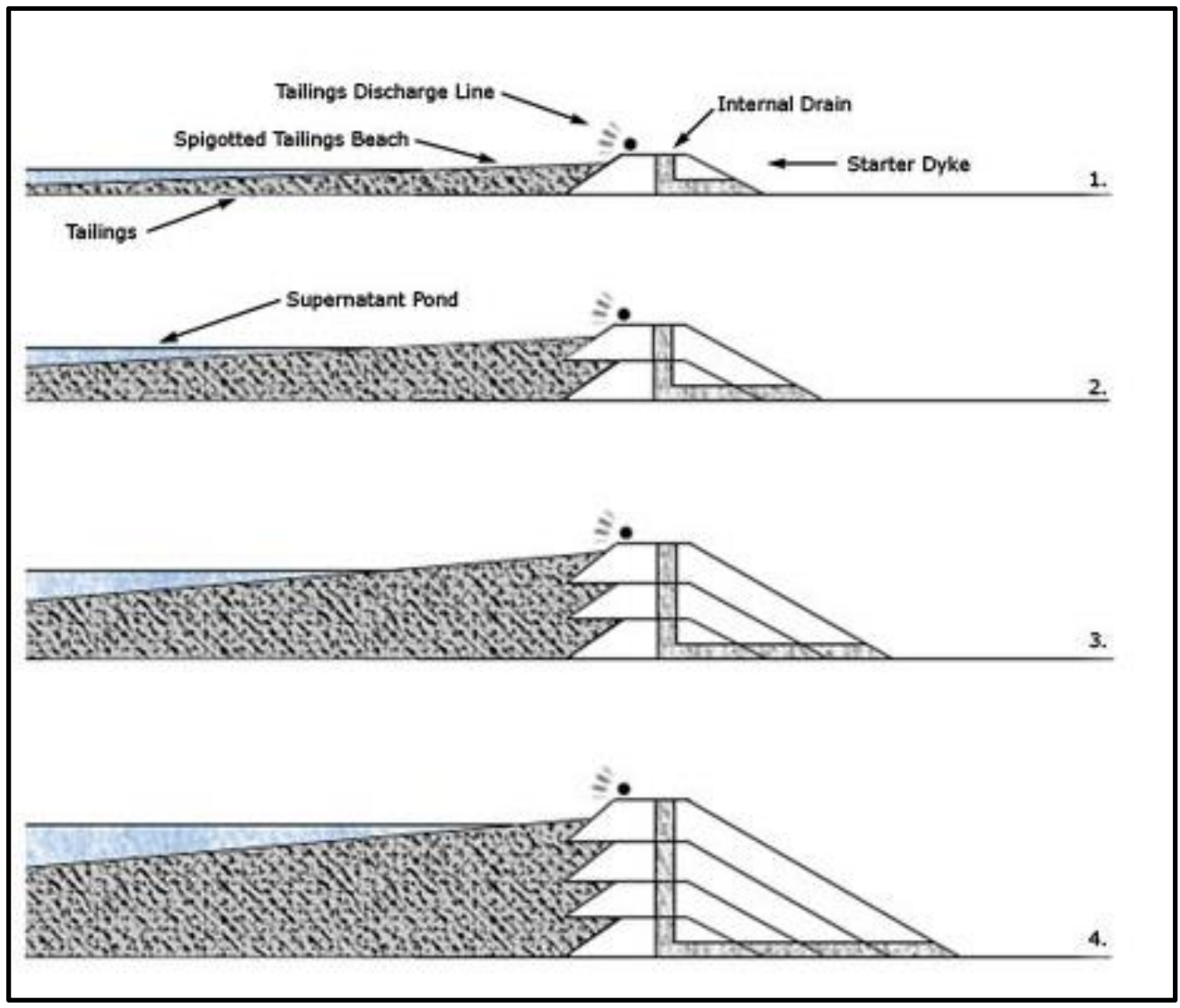

Figure 5: Centreline method of embankment construction.

The design incorporates the internal drainage zones that are similarly found in the downstream method. Therefore, the free water can encroach closer to the dam crest than the upstream method without the worry of increasing the phreatic surface and causing a potential failure risk. However, a Centreline Dam cannot be used as a large water retention facility solely due to the subsequent raises being partially built on consolidated tailings. A suitable decants emptying system needs to be installed to prevent the free water submerging the beach around the dam crest. In many cases, the centreline design is a good compromise between the seismic risk and the costs associated with construction. In a modification to this method is to reduce the volume of construction material placed in the downstream shell of the embankment, the angle of the upstream crest advance over the tailings is calculated during the design phase following stability and seepage analyses. Rockfill is usually utilized in this technique to gain a higher angle, rather than the coarse tailings fraction to reduce the risk of instability.

In countries where upstream construction is not permitted due to seismic risk, the 
modified centreline method may not be also permitted due to the concept of partially placing construction material on the existing tailings beach $[12,13]$.

\section{Impacts of Tailings Dam Collapse and Safety Hazards}

The collapse of any tailings dam can have extensive negative impacts on the surrounding environment such as:

1) Flooding and contaminating water streams and rivers.

2) In many instances even poison water supplies serving large populations.

3) Covering large land areas with wastes rendering them unusable and very difficult and costly to reclaim.

4) Crushing and destructing homes and infra structures.

5) Accumulation of poisonous residues in plants and animals.

6) Loss of animal lives and above all loss of human lives.

Failure of tailings dams may follow one of the following failure modes:

i) Dam Instability.

ii) Overtopping.

iii) Internal erosion.

Long-term safety hazards other than complete embankment failure can also result from such reasons as seepage, dust, long-term erosion. Tailings may retain their hazard potential for hundreds of years, which requires efficient measures to contain them in the long term.

From the report of the International Task Force for Assessing the Baia Mare and Baia Borsa Accidents in Rumania (January and March 2000) it can be seen that usually, there is a combination of reasons for the failure: The accidents were in summary caused by:

i) The use of an inappropriate design.

ii) The acceptance of that design by the permitting authorities.

iii) Inadequate monitoring and dam deficient construction in addition to operation and maintenance shortcomings.

Mentioned design and operational faults, which contributed to the failure were:

i) Use of a closed circuit system with no specific provision for the emergency discharge/storage of excess water.

ii) Inadequate care in the disposition of tailings within the dam and lack of homogeneity of the tailings.

iii) Non operation of the hydro- cyclones in very low temperatures.

iv) Failure to observe the design requirements for tailings grades for embankment wall construction [14]. 
Tailings dam modes of failures are classified into the different modes as already mentioned. More can be said on this as mentioned in the following three aspects:

i) Dam Instability.

ii) Water Management.

iii) Earthquakes.

\section{i) Dam Instability}

Such instability has caused many tailings dams incidents, which were resulting from one or combination of the following four reasons:

a) Unsatisfactory foundations: Poor foundation means the soil or rock layer below the dam is not qualified to support the dam. This hazard can lead to partial or complete dam failure. This is allied to site investigation because the weaknesses revealed by the dam failures should have been detected during the site investigation. It does not necessarily imply that the site investigation was inadequate, but the dam designer may not have made the correct assumptions from the site investigation reports.

Complete and partial failure cases which were investigated by Karl Terzaghi and quoted by him include many examples of such failures: In the first, where the surface layers of clayey soil had not been stripped prior to the construction of the dam. The result was that the base of the dam slid forwards, causing failure. In a second case, an $8 \mathrm{~m}$ high tailings dam was built on gently sloping ground on a clay stratum about $6 \mathrm{~m}$ thick overlying a shale/mudstone bedrock. Its impoundment had been filled completely 8 years before it failed. The failure was attributed to artesian water pressure in the bedrock developed by the seepage of water from other impoundments further up the slope, combined with tensile strains induced in the clay stratum by old underground mine workings. In a third case, a clay layer in the foundation of the dam sheared when the dam reached a height of $79 \mathrm{~m}$. This caused a $240 \mathrm{~m}$ long section of the dam to slump. It was stabilized by the use of rock drains and toe weight.

More cases were documented of foundation problems where engineering solutions were attempted. First is the case of a dam that was founded on about $50 \mathrm{~m}$ depth of material overlying lava flows. There appears to have been a layer of weaker material lying over the lava flows, and when the dam had reached a height of $25-30 \mathrm{~m}$, the dam slid forwards on this deep layer. The dam was stabilized by draining the layer into excavated tunnels from the existing underground mine workings, and constructing a rock buttress at the dam toe that would act as toe weight.

Another, but unsuccessful engineering solution was of the Aznalcóllar tailings dam in Spain. The dam failed in April 1998 when it had reached a height of $27 \mathrm{~m}$. Length of the dam of about $600 \mathrm{~m}$ swung open forming a breach about $45 \mathrm{~m}$ wide and releasing an estimated $5.5 \times 10^{6} \mathrm{~m}^{3}$ of acidic tailings that flooded over an area of approximately $2.6 \times 10^{3}$ hectares of farmland. The dam was founded on about $4 \mathrm{~m}$ thickness of alluvium, overlying marl, which may have contained pre-formed slip surfaces. The impoundment, about $2 \mathrm{~km}$ long and $1.2 \mathrm{~km}$ wide, was along one side of the flat valley of the river Agrio. The tailings in the impoundment was were 
particularly heavy, with a bulk density of $28 \mathrm{kN} / \mathrm{m}^{3}$. The failure occurred where a dividing dam met the main dam. In 1995, some grouting was carried out from the main dam crest to reduce leakage. 42 relief wells were placed towards the end of 1997 along the downstream toe, through the alluvium and about $1-1 \frac{1}{1 / 2} \mathrm{~m}$ into the marl, and for several months they collected $1000 \mathrm{~m}^{3} / \mathrm{hr}$ of seepage that was pumped back. There was some evidence to suggest that the main dam failed north of the dividing dam, prior to the bodily movement of the main dam adjacent to and south of the dividing dam on a shear plane deep in the marl.

b) Instability of the downstream slope: The dangers of allowing the phreatic surface to move so far downstream as to intersect the downstream slope of a dam are the same in tailings dams as in conventional earthfill dams. If the rate of construction raises the vertical height sufficiently slowly then construction pore pressures can dissipate, and appreciable pressures seldom develop within the dam itself creating no threat to the stability to the downstream slop. Pore pressures are raised however by the rising impoundment, which usually rises at the same rate as dam construction which means that rate of construction must be kept slow enough to allow pore pressure dissipation. Moreover, if the rate of tailings deposition is slow enough to keep a long unsaturated beach, then this can help in keeping the phreatic surface inside the dam low enough. Trouble can arise when pond level rises quickly saturating the beach and bringing the edge of the open water closer to the dam axis.

Rainwater gullies in the downstream slope can worsen the situation, and if any of them is deep enough, then the phreatic surface may intersect with it causing sloughing of the materials and creating possible circular slip surface. If this behavior continues for too long, unobserved, larger and larger rotational slips occur, endangering the stability of the whole dam.

In some cases, the phreatic surface can be moved back from the slope by the installation of horizontal bored drains. In other cases, additional drainage has been installed in the form of pumped vertical wells. While such measures might serve the purposes, in particular situations, it is advisable always to optimize the rate of raising the tailings with the rate of pore pressure dissipation, which can be measured by use of open pipe piezometers.

c) Superimposed loads: Failures had occurred when loads were added to dams retaining tailings by increasing the height of the dam while retaining the same downstream slope.

An example is cited from Lower Indian Creek lead mine, USA, 1960. The impounding earthfill dam was built in 1953 to a height of $14 \mathrm{~m}$ and subsequently raised several times by the addition of earthfill. In 1960, slumping occurred in the 1 on 2 downstream slope. The dam was saved by the addition of rockfill toe weight, placed with an outer slope of 1 on 3 . The dam remained in service and was raised between 1971 to 1976 with cycloned sand fill, ultimately reaching a height of $25.3 \mathrm{~m}$. Another case is that of Maggie Pye china clay, UK, 1970. The $18 \mathrm{~m}$ high dam suffered slope failure immediately after completion of a dyke on the crest to raise the dam; following a period of heavy rain, high pore pressures, together with the 
added weight of the new fill were thought to be the causes for the failure. In this case, $15,000 \mathrm{~m}^{3}$ of tailings were released.

\section{ii. Water Management}

A high water level can result from heavy precipitation events or inappropriate decanting, which ends in overtopping the embankment crest resulting in failure. In so many cases, water ponded in a tailings impoundment is removed by evaporation, pumping from a floating barge, or decanting into a tower acting as spillway that exits the impoundment through a culvert or pipe beneath the tailings dam. One of the most common causes of unintended dangerous rises of pond water levels is inadequate behavior of decants. This may be produced by debris blockage, crushing and/ or fracture of the outlet passing under the dam, or by unanticipated flood. An example of decant towers is shown in Figure 6. Damage to decant towers caused by ice has also been reported.

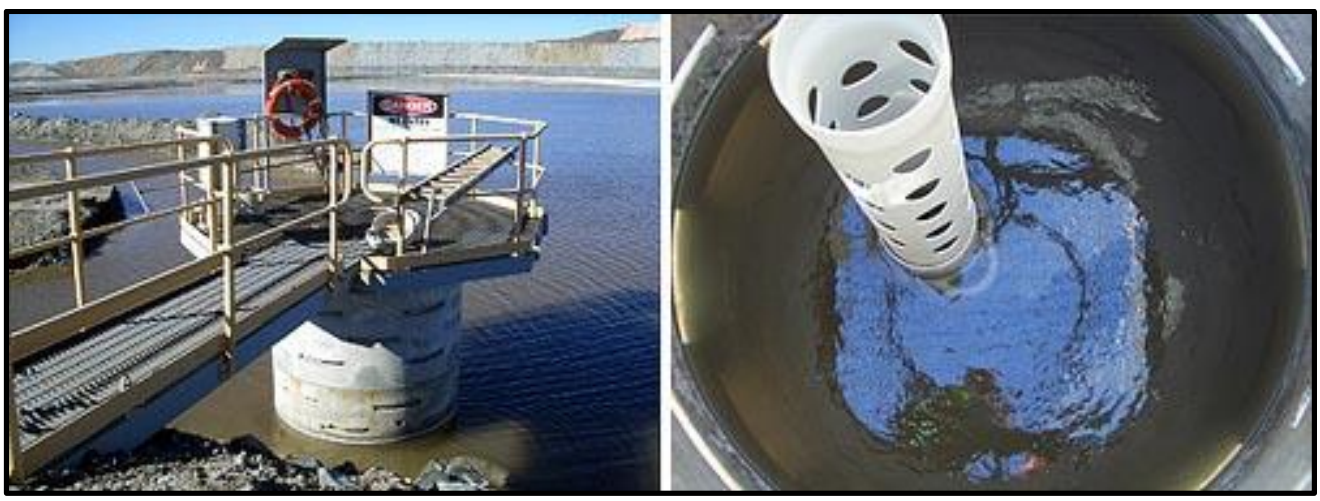

Figure 6: Decant tower with walkway (left), view inside the tower showing riser pipe and submerged decant collars (right) [15].

In Casapalca, Peru, several tailings dams were built by upstream method, up to $107 \mathrm{~m}$ high, which used a complex array of pipe type decant structures and inadequately sized stream bypass channels. Five separate dam failures resulted from failures in these systems. Another example is from Blackbird, USA, Cobalt mine where the metal culvert under the dam corroded and partially collapsed. Suspended tailings discharged into downstream drainage, but no embankment breach occurred. Contrary to this, the failure in 1974 of three tailings impoundments that had been built in sequence within a narrow valley for Galena silver mine, USA, when during a rain on a snow event that caused a 100 year flood, a blockage diverted a large portion of the flood into the uppermost impoundment. Its decant could not accept this large flow, causing the upper dam to fail by overtopping, leading to a cascade failure of the others. Released tailings covered about 5 acres of land, including part of a highway and main line railway.

Sufficient freeboard under all circumstances and all along a tailings dam is one of the most important prerequisites for safety. This calls for a sound water balance of 
the tailings disposal system considering all the components of inflow under the varying conditions of operation and the climatic conditions. Extreme situations with low frequency of reoccurrence need also to be checked. In parts of the world subjected to long periods of frost, failures have occurred as an indirect result of freezing. One example is Kimberley iron mine, British Columbia, when in 1948, slope failure occurred during a period of high snowmelt and spring runoff that raised the phreatic surface while the surface of the slope was frozen. A large tailings flows slide developed, and frozen blocks of material were seen in the flowing mass. In another reported case; extensive sloughing of downstream slope was attributed to freezing and growth of ice lenses accompanied by the development of piping during the first few days of a spring thaw.

\section{iii. Earthquakes}

Dams built by the Upstream Method are more susceptible to damage by earthquake shaking. There is a general suggestion that this method of construction should not be used in areas where there is a risk of earthquake. Dams built by the downstream method, in cases where there are sufficient volumes of the coarser fraction in the tailings, or those built from borrowed clayey fill as water retaining dams, are much less prone to damage by earthquake shaking. Harry Bolton Seed (1922-1989) had suggested in the $19^{\text {th }}$ Rankine Lecture in 1979 titled "Considerations in the earthquake-resistant design of earth and rockfill dams" that it was noteworthy that no failures have been reported in dams built of clayey soils even under the strongest earthquake shaking conditions imaginable, and that all cases of slope failure reported have involved sandy soils, which strongly suggests a liquefaction type of failure.

One history case is to be cited here from the Barahona $61 \mathrm{~m}$ high dam, Chile, 1928. The dam was built by the Upstream Method with downstream slopes of 1 on 1 . The dam failed during the Talca earthquake of magnitude 8.3, producing a breach of $460 \mathrm{~m}$ wide. The released tailings flowed down the valley, killing 54 people. In another case of Bellavista, Chile, 1965, a $20 \mathrm{~m}$ high dam built by the Upstream Method with downstream slope of 1 on 1.4, failed during the La Liqua earthquake of 7.7 magnitude. At the time, only $8 \mathrm{~m}$ separated the edge of the pond water from the dam crest.

Many more such failures are recorded and documented in the literature. Failure of a Tailings Dam by itself, while causing an inconvenience, may not have in some cases seriously been damaging consequences nor cause any loss of life, but this depends on the size of tailings storage, the proximity from rivers and water courses in addition to being located in remote and undeveloped areas $[16,17]$. 


\section{Multiple Failure Modes Case Studies}

While many examples of tailings dams' failures are mentioned in the preceding pages, it is worthwhile, however, to illustrate how a combination of many failure modes can result in such failure. In the following is the case of Merriespruit Harmony Gold Mine Tailing Dam in South Africa, 1944, which sheds more light on such an event.

In this case, overtopping due to an inadequate freeboard was ample to trigger static liquefaction and toe material erosion causing a massive flow slide to be initiated soon after. The Harmony tailings were quite fine-graded with more than $60 \%$ finer than $74 \mu \mathrm{m}$. However, these fines were also essentially cohesion-less and once an area of the dam toe was eroded, and local slopes were increased to the range of $2 \mathrm{H}: 1 \mathrm{~V}$, static liquefaction and the massive flow slide were inevitable. To add to these factors mismanagement of operations was decisive in accelerating the failure at a time when the possibility of saving the dam was at hand.

Progress of this tailings dam had utilized a "paddock" system for tailings management. Paddock systems are relatively common in South Africa and are essentially upstream constructed tailings impoundments with little freeboard and relatively saturated dam shells [18]. For detailed information on the Paddock system, please refer to reference [19].

The mine was located near the town of Merriespruit. On the $22^{\text {nd }}$ February 1994, the Merriespruit Tailings Dam failed by overtopping as a consequence of heavy rains causing static liquefaction and flow slide of part of the embankment once enough toe material was eroded away. Water mismanagement was to blame, which caused $600,000 \mathrm{~m}^{3}$ of tailings to mobilize out of the impoundment where the flow eventually stopped $2 \mathrm{~km}$ away in the town of Merriespruit drowning 17 people, and scores of houses were demolished. Figure 7 shows the extent of the damage to the town and the scale of the breached embankment.

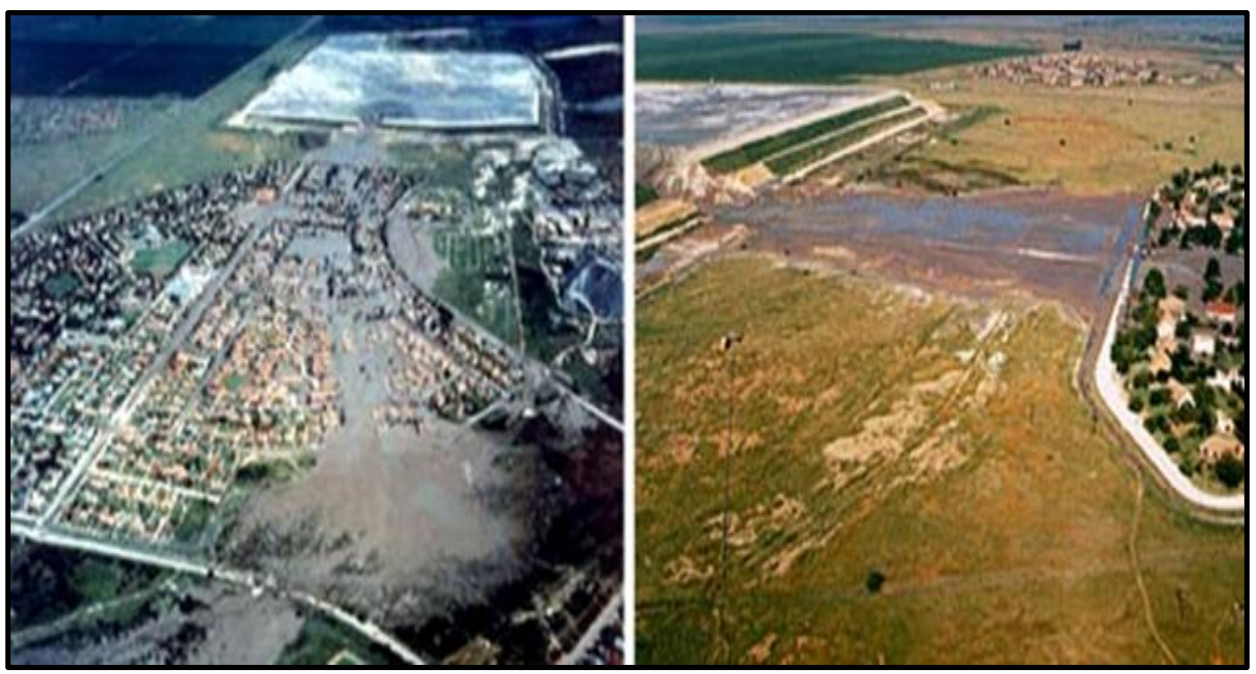

Figure 7: Merriespruit tailings engulf the town. 
The $31 \mathrm{~m}$ high embankments had problems prior to the major failure. Small slips caused the impoundment to close temporarily, and only mine water with small amounts of tailings were deposited. The deposition of these tailings caused the floating material (supernatant pond) to move to the opposite side of the impoundment away from the decant system rendering it inoperable. A satellite recorded the transition stages of the decant pond relocation as more tailings were deposited with the mine water. Heavy rains that fell on the day of the failure (30-55 $\mathrm{mm}$ in 30 minutes), combined with no possibility of emptying due to the idle decant system, caused the overtopping. The failure event is illustrated in Figure 8. A close up of the breach is shown in Figure 9.

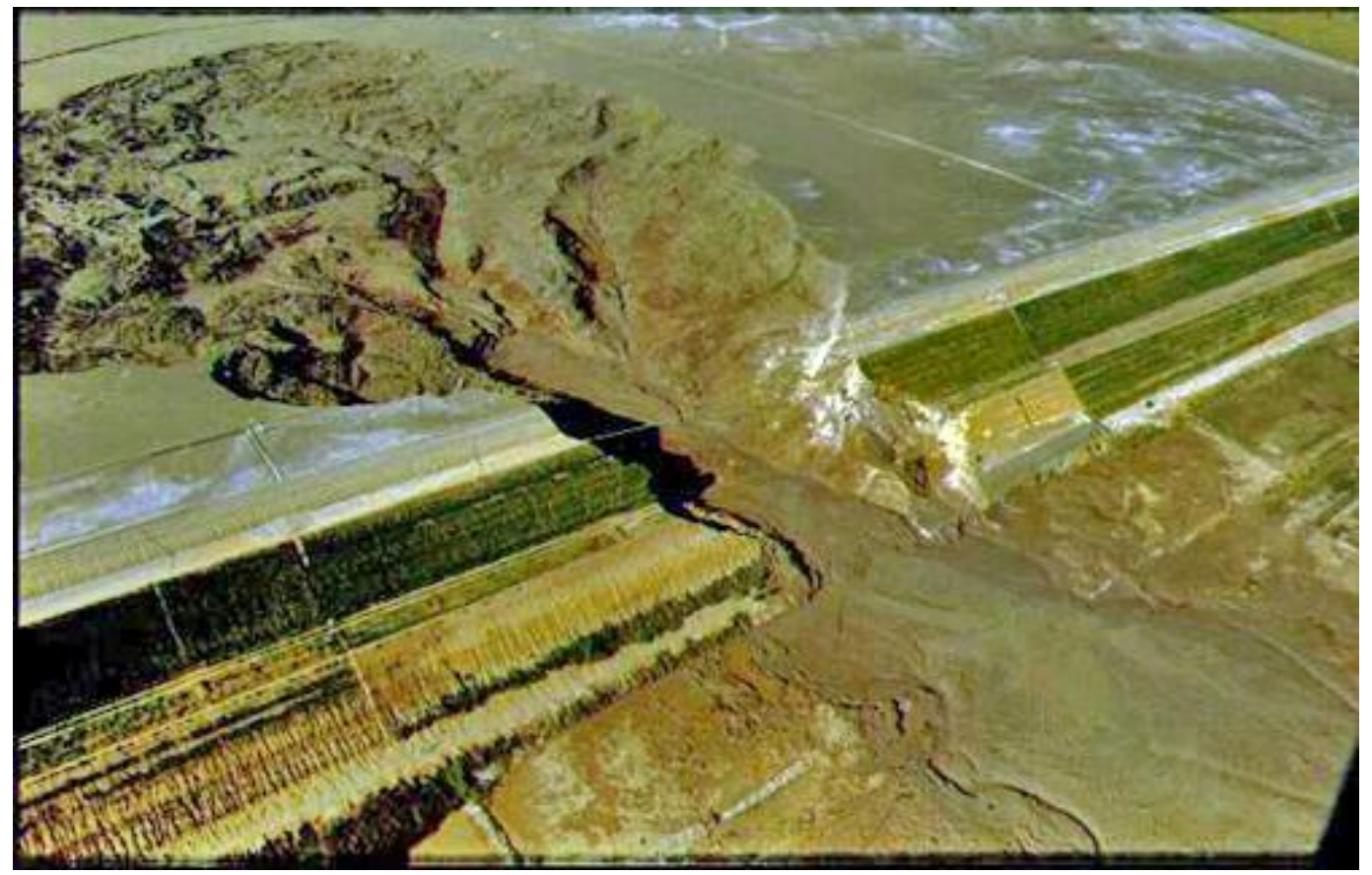

Figure 8: Aerial of the Merriespruit failure. 


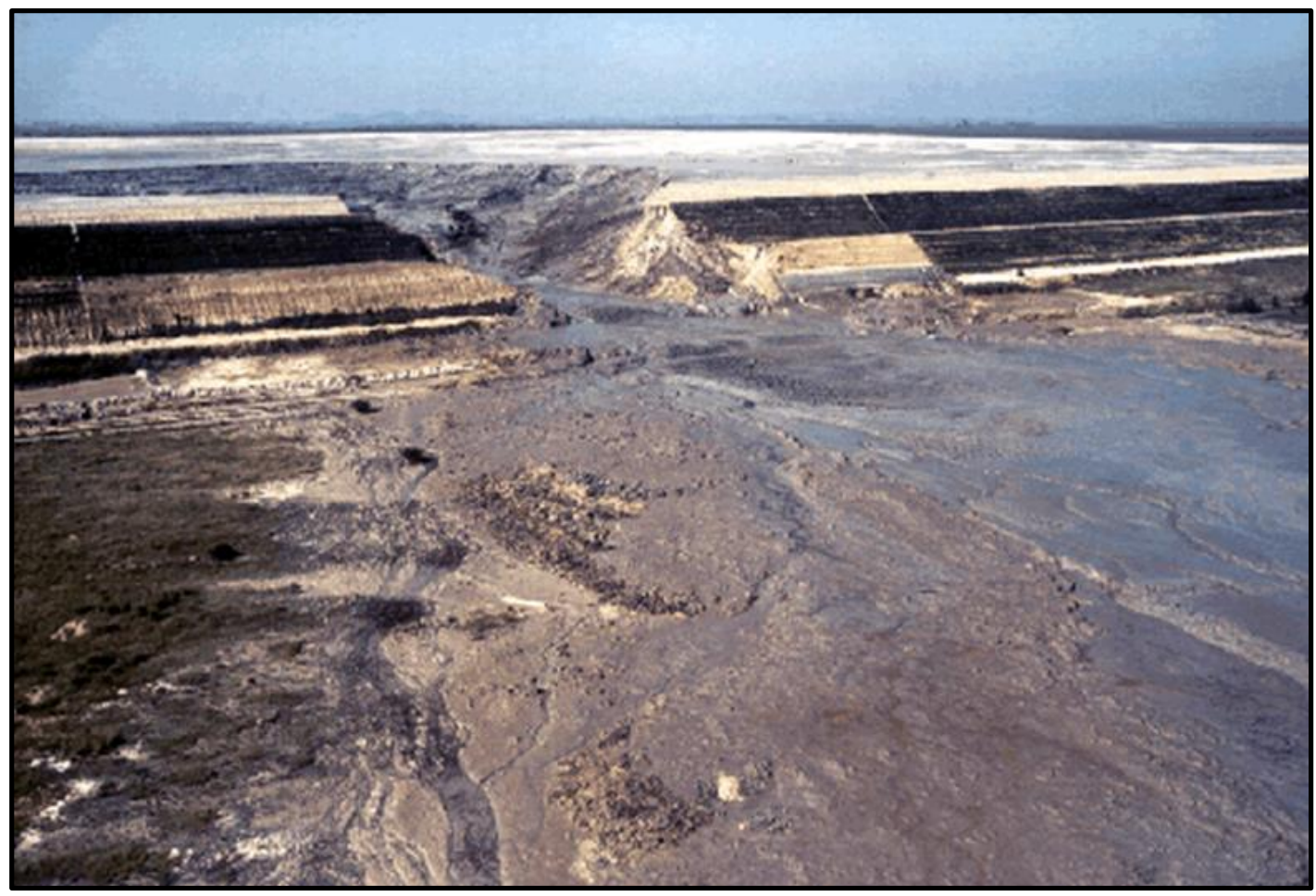

Figure 9: Close-up of the embankment breach.

The failure could have been prevented if a suitable operating manual, and emergency plan had existed and been implemented successfully. The operation of the facility leading up to the major failure was outside the designed operating procedures. The facility was closed as a result of earlier embankment slips but still process water and tailings were being discharged to the impoundment. This suggests that an emergency plan was not in place to implement intervention actions, or it could have been that documented procedures were overridden by an individual making an executive decision. Whichever the case may have been, the lack of understanding of the operational procedures and the seriousness of the events prior to the main failure had not been realized. Moreover, if a well-structured and executed operational plan had existed, then the tailings operator(s) would have known to intervene, continually monitor the closed impoundment for change and prevent further discharge to the facility.

The position of the supernatant pond and its ability to decant was lost which suggests that the monitoring procedures were inadequate to notice the change in the pond geometry and location. Alternatively, the tailings operators may not have been trained to realize the consequences of pond migration away from the decant system as a result of single point deposition of the process water and tailings. A management structure documenting individual responsibilities, operating procedures and contingency measures would have been sufficient to identify and prevent the initial localized slips and how the facility was to be managed thereafter. Having a suitable tailings management system implemented could have prevented 
this failure from occurring [20].

The importance of rigorous management tailings dam operation cannot be over emphasized, such plans were prepared and followed in cases such as the Endako Mine (British Columbia, Canada and AngloGold, South African) [21].

\section{Conclusions, Lessons Learned and Recommendations}

Many conclusions can be drawn from a thorough study of documented tailings dams' failures and incidents. Lessons can be drawn from these studies which enhance the current knowledge of dams' behavior and faults committed in their design, construction and operation. The consequences of these failures have been heavy economic losses, environmental degradation and, in many cases, human losses. Even with the current improved technology for the design and the improved construction and operation of Tailings Dams, failure of such dams has continued to occur, which should be enough reason to continue research and improvements to make such dams as risk free as possible.

The conclusions and lessons learned from these failures shall be considered as additional resources for having safer tailings. Such conclusions and lessons, may be summarized by, but not limited to, the following:

1. Data related to causes and types of reported tailings failures, and incidents should be looked at with great caution; inaccuracies could have crept into them since different people had reported them, using different forensics, at different times, and may be with different purposes. Information on failures of tailings dams due to incorrect management, which have resulted in extensive long lasting and costly damages to the environment and considerable human fatalities, may be the most misleading for the obvious reasons of covering up attempts to relieve the operators of their personal responsibility and the heavy penalties that they may face.

2. Available statistics indicate that total number of accidents, using an estimate of 3500 active tailings dams in the world, has gone down from over 50 during the 1960s-1980s to less than 30 in the 2000s-2010s. This could be due to more awareness of the following:

- The upstream construction method is a hazardous one and especially so in seismic areas. Indeed, Chile has forbidden such a construction type.

- Failures at operating facilities are more than five times more than at closed abandoned facilities. Which can mean that stricter control over operations activities should be exercised.

- The percentage of all failures and incidents cases whose causes are reported as "unknown or not available" makes $26 \%$ of all cases. 
Subject to this limitation, it may be seen from the remaining cases that:

i) Overtopping, seismic and slope stabilities are the strongest categories making 42 to 48 accidents for each, whereas.

ii) Seepage, structural inadequacy and foundation come in a second category making 20-25 accidents for each.

iii) Erosion and external erosion are the smaller category with 11 accidents.

3. The consequences of failures are not necessarily correlated, in one way or another, with dam height or pond volume, for example:

(i) A small $\left(300,000 \mathrm{~m}^{3}\right)$ release at Stava tailings dam failure (Italy, 1985) killed hundreds of people. That was because the valley downstream funneled the release toward a village a few kilometers away. Stava became one of the most mortiferous tailings accidents in history, whereas.

(ii) The more recent Samarco (Brazil, 2015) huge release ran hundreds of kilometers, killing dozens of people only.

(iii)Mount Polley (Canada, 2014) mostly ended in a lake nearby, with no victims [22].

4. The causes in many failures could be attributed to lack of attention to details. Original design heights are often exceeded, and the properties of the tailings can change with time. Lack of water balance may be due to rising phreatic levels causing local failures that produce crest settlements, which can lead to "overtopping". Other causes include problems of foundations with insufficient investigations, inadequate or failed decants, slope instability, erosion control, structural inadequacies and additional loading of impoundments.

5. In the design, construction, operation and closure of dams, impoundment risks potential to downstream shall be minimized by emphasis on the following requirements:

(i) Detailed site investigation by experienced geologists and geotechnical engineers to determine possible potential for failure, with insitue and laboratory testing to determine the properties of the foundation materials.

(ii) Application of state of the art procedures for design.

(iii)Expert construction supervision and inspection.

(iv)Laboratory testing for "as built" conditions.

(v) Routine monitoring.

(vi) Safety evaluation for observed conditions, including "as built" geometry, materials and shearing resistance. Observations and effects of piezometric conditions.

(vii) Dam breaks studies.

(viii)Periodic safety audits. 
6. Regulatory Authorities should be more concerned about the safety of Tailings Dams, which come under their jurisdiction and should require periodic reviews carried out by appointed specialists. In some countries, approval had to be obtained for specific stages of construction, causing the stability, general condition and safety to be automatically checked from time to time [23].

7. Monitoring of dams is very important to detect any progressive conditions leading to failure before it occurred. Technologies and modern instrumentation exist today, which together with visual inspections can detect the main factors directly influencing dam safety, these are:

(i) Seepage discharge through the dam itself, through the foundations and abutments.

(ii) Position of the phreatic surface and any danger that it might emerge on the slope.

(iii)Pore pressure development in the embankment.

(iv)Seismicity and induced dynamic pore pressure.

(v) Horizontal and vertical movement of the starter dam crest and of the downstream slope.

(vi)Amount that the dam crest is above water level (Freeboard).

(vii) Beach width, which should be as large as possible.

(viii)All tailings placement procedures [24].

8. In a majority of failures associated with large tailings damages, the absence was noticed of a risk assessments study with a meaningful updated emergency action plan. The same importance attached to these for conventional dams must also be given to tailings dams. They are valuable assets, which can help in minimizing the damages and human fatalities through fast actions for evacuation of endangered population and for quick remediation measures. This requires good communication arrangements with the public to raise awareness and secure cooperation in an emergency case. Effective communication between site management and headquarters helps to take prompt relief and repair actions, such communication allows the community as well as the responsible organizations to participate in planning the best emergency preparedness arrangements.

If the community understands the real consequences of a spill before one occurs, it will be better prepared to deal with the emergency. Among other things, the general anxiety leve1 will be reduced. If, on the other hand, the community is uninformed, its anxiety and mistrust may prevent the mining company from being able to communicate with it effectively during such an emergency [25]. 


\section{References}

[1] Gavett, G. (2012) Tailings Dams: Where Mining Waste is Stored Forever. Frontline, 30th July, 2012.

https://www.pbs.org/wgbh/frontline/article/tailings-dams-where-miningwaste-is-stored-forever/

[2] Wikipedia (2020). Syncrude Tailings Dam. Web Page retrieved on 26th March 2020. https://en.wikipedia.org/wiki/Syncrude_Tailings_Dam

[3] Davies, M. P. (2002). Tailings Impoundment Failures: Are Geotechnical Engineers Listening?. Waste Geotechnics, Geotechnical News, p.31 September 2002.

http://www.pebblescience.org/pdfs/Dam_failuresDavies2002.pdf or https://www.semanticscholar.org/paper/Tailings-Impoundment-Failures\%3AAre-Geotechnical-Davies/ba53180a3345a44e1e5f8e56b67a7792150c3c30

[4] Industrial Global Union (2009). What are tailings dams?. Web Page retrieved on 26th Mach 2020 http://www.industriall-union.org/why-you-need-to-knowabout-tailings-dams

[5] ICOLD-UNEP (2001). Tailing Dams lessons learned from Dangerous occurrences and incidents. Bulletin 121, 2001. http://www.unep.fr/shared/publications/pdf/2891-TailingsDams.PDF

[6] World Information Service on Energy Uranium Projects (2019). Chronology of major tailings dam failures. Last updated on 29th December 2019. Retrieved on 26th March 2020 http://www.wise-uranium.org/mdaf.html

[7] Larrauri, P. C. and Upmanu, L. (2018). Tailings Dams Failures: Updated Statistical Model for Discharge Volume and Runout. Environments Journal, Vol. 5, Issue 2, 28, 15th Feb 2018, MDPI Publication.

https://www.mdpi.com/2076-3298/5/2/28

[8] Blight, G. E. (1998). Construction of Tailings dams. From ICME-UNEP publication "Case Studies on tailings dams Management", pp.9-10, OttawaParis 1998. http://wedocs.unep.org/bitstream/handle/20.500.11822/26442/Tailings_mana gement.pdf? sequence $=1 \&$ isAllowed $=y$

[9] Wikipedia (2020). Wheal Jane. Web page retrieved on 28th March 2010 https://en.wikipedia.org/wiki/Wheal_Jane

[10] Wheal Jane Mine, Cornwall. Web page retrieved on 28th March 2010 http://www.cornwall-calling.co.uk/mines/carnon-valley/wheal-jane.htm

[11] U.S. Environmental Protection Agency (1994). Design and Evaluation of Tailings Dams. Technical Report: EPA 530-R-94-038 NTIS PB94-201845, August 1994.

https://archive.epa.gov/epawaste/nonhaz/industrial/special/web/pdf/tailings.p df 
[12] Engels, J. (2004). Conventional Impoundment Storage - The current techniques. Based on $2006 \mathrm{PhD}$ thesis with the title "An expert management system for surface tailings storage". Article published on Tailings.info web site and retrieved on 29th March 2020. http://www.tailings.info/disposal/conventional.htm

[13] Internet Archives (2020). Properties of Tailings Dams. Web page retrieved on 29th March 2020.

https://web.archive.org/web/20111001213037/http:/www.mining.ubc.ca/facu lty/meech/MINE290/Tailings\%20Dam\%20Construction\%20Methods.pdf

[14] Nilsson, A. (2001). Safe Dam Construction. From proceedings of the seminar on "Safe Tailings Dams Construction", held on 20-21 September 2001 Gällivare, Sweden https://ec.europa.eu/environment/waste/mining/pdf/mining_dams_seminar.pd f

[15] Engels, J. (2020). Water Management Considerations for Conventional Storage. Based on $2006 \mathrm{PhD}$ thesis with the title "An expert management system for surface tailings storage". Article published on Tailings.info web site and retrieved on 30th March 2020. http://www.tailings.info/technical/water.htm

[16] Xinyi, W. (2012). Generic Decision Making on the Retreatment of Copper Tailings Dams. M.Sc. thesis, University of British Columbia (Vancouver). July 2012.

https://open.library.ubc.ca/cIRcle/collections/ubctheses/24/items/1.0072943

[17] ICOLD (1979). Tailing Dams lessons learned from Dangerous occurrences and incidents. Bulletin 21, 1979.

http://www.unep.fr/shared/publications/pdf/2891-TailingsDams.PDF

[18] Davies, M. P. (2002). Tailings Impoundment Failures: Are Geotechnical Engineers Listening?. Waste Geotechnics, Geotechnical News, P 33 September 2002. http://www.pebblescience.org/pdfs/Dam_failuresDavies2002.pdf

[19] McPhail, G. I. and Wagner, J. C. (1987). Disposal of Residues. Chapter 11, pp.669-671,Conference of the Extractive Metallurgy of Gold, South Africa, 1987, Johannesburg South Africa. http://www.saimm.co.za/Conferences/ExtractiveMetallurgyOfGold/0655Chapter 11.pdf

[20] Tailpro (2020). Merriespruit Tailings Dam Failure, Virginia, South Africa http://www.tailings.info/casestudies/merriespruit.htm

[21] Engels, J.(2020). Merriespruit Tailings Dam Failure, Virginia, South Africa. Based on $2006 \mathrm{PhD}$ thesis with the title "An expert management system for surface tailings storage". Article published on Tailings.info web site and retrieved on 31st March 2020. http://www.tailings.info/casestudies/merriespruit.htm 
[22] Blight, G. E.(1998). Construction of Tailings dams. From ICME-UNEP publication "Case Studies on tailings dams Management", pp16-19, OttawaParis 1998.

http://wedocs.unep.org/bitstream/handle/20.500.11822/26442/Tailings_mana gement.pdf? sequence $=1 \&$ isAllowed $=y$

[23] Oboni, F. and Oboni, C. (2017). Hundred years of lessons learned in tailings dams failures. Riskope blog post on $22^{\text {nd }}$ February 2017. Retrieved on 1st April 2020. https://revistaminerios.com.br/hundred-years-of-lessons/

[24] ICOLD (1979). Tailing Dams lessons learned from Dangerous occurrences and incidents. Bulletin 21, 1979. http://www.unep.fr/shared/publications/pdf/2891-TailingsDams.PDF

[25] Roca, M., Murphy, A., Walker, L. and Vallesi, S. (2019). A review of the risks posed by the failure of tailings dams . Chapter 3-Monitoring. HR Wallingford working with water. Contributors: Macleroy C, Gimeno O., January 2019. https://damsat.org/wp-content/uploads/2019/01/BE-090-Tailings-dams-R1Secured.pdf

[26] ICME-UNEP (1998). Emergency Response During the Omai Tailings Dam Failure. Case studies on Tailings Management, pp.50-51, November 1998. http://wedocs.unep.org/bitstream/handle/20.500.11822/26442/Tailings_mana gement.pdf? sequence $=1 \&$ isAllowed $=y$ 